\title{
Heat rises over Brussels FP5 proposals
}

[BRUSSELS] Tensions are already high over the European Union (EU)'s fifth Framework research programme (FP5), due to run between 1998 and 2001, both among the various political bodies that must approve it and within the scientific community, concerned at the way it is likely to be carried out.

These tensions centre on how the European Commission intends to concentrate its proposed budget - expected to be ECU15 billion (US\$13 billion) - how the role of bastc research will be protected, and how a proposed complex new system of management can be made to work efficiently.

Many of these issues surfaced last week at a meeting in Brussels of representatives of the programme's end-users, academic and industrial researchers, and advisory committees to the commission, called to discuss the commission's draft proposal for the Framework programme. This will become a formal proposal by the end of March.

The draft proposal envisages three broad thematic programmes, interlaced with three policy-oriented 'horizontal' programmes (see Nature 385, 665; 1997). The thematic programmes include so-called key actions, research programmes directed to strategic goals, as well as untargeted programmes for generic technologies and basic research.

The meeting gave its general approval to the goal of concentrating funds on a limited number of activities. But those present pressed for more key actions - for example, in the areas of climate research and polar sciences - as well as an additional thematic programme for energy, which at present is subsumed within a thematic programme called 'Promoting competitive

\section{Lack of focus 'holds back European research'}

[BRUSSES] An independent five-year assessment of the European Union (EU)'s Framework programmes for research has concluded that European research is "underachieving" because of a lack of focus and a legal structure that hinders the development and implementation of a truly European strategy.

The report, by an independent panel of experts headed by Etienne Davignon, a former European research commissioner (right), stresses that the quality of research assessed was adequate but that the work often lacked clear goals. It calls for a radical rethink - a "leap forward" - in the formulation of strategy for the next, fifth, Framework programme ( $(\mathrm{P} 5)$, now being developed (see above).

Many recommendations are being implemented or are included in the European Commission's draft proposal for $\mathrm{P} 5$. For example, procedural changes have been introduced to reduce what the Davignon report highlights as "unacceptable levels of bureaucracy and delays" in approving grants. But the report goes further, suggesting that the

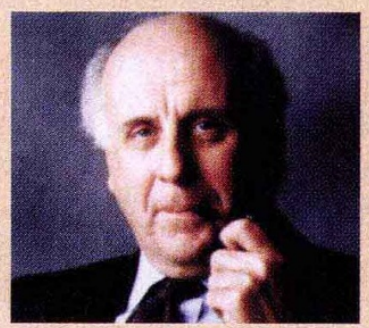

commission should consider increasing staffing, or delegating some tasks to outside bodies.

In line with new commission thinking, it also says that 'structural funds' the EU's subsidies to poor regions - should be used for research, and that 175 's budget should be more flexible, allowing priorities to be changed quickly.

But the report also makes a plea for two high-level changes to be made to the legal framework governing EU research, to allow programmes to run more effectively and efficiently. First, it says that the union's Maastricht Treaty should be changed to eliminate the requirement for a unanimous vote on Framework research programmes by the council of ministers. The power of single countries to veto an entire programme has meant that the EU research effort tends towards "an aggregate of national and sectoral desire and ambitions". The report suggests that the treaty should be amended to allow for qualified majority voting.

Second, Davignon's panel says that the commission should be given a freer hand in implementing research programmes approved. Individual programmes are at present controlled by programme committees made up of officials from member states. The need for most decisions to be approved by these committees - 18 control the current Framework programme - slows down procedures, says the report.

The report recommends replacing these committees by a single, high-level committee. This "union committee", appointed by and reporting to the council of ministers, would monitor the commission's implementation of research programmes and act as an official advisory body to the council.

All the report's recommendations will be considered by the commission in preparing its formal proposal to the council and the European parliament at the end of this month. A.A. and sustainable growth'

Jan Borgmann, head of the European Science and Technology Assembly (ESTA), warned the meeting that the conflicts over where FP5 should concentrate its efforts are likely to increase when the commission's formal proposal is presented to the European parliament and the council of ministers. Everyone will lobby for their own interests, said Borgmann. "The commission will have a hard time," he said, but he stressed that ESTA will support its efforts to resist pressure to widen the scope of the programme.

Most participants at the meeting also approved the concept of the dual approach of targeted and untargeted programmes. But members of CREST, the EU's Scientific and Technological Research Committee which comprises representatives of member states, warned that the council of ministers is unlikely to be enthusiastic about the commission's concept of a separate budget for generic technologies and basic research, which would allow a 'bottom-up' approach to longer-term research aims. The council of ministers is made up of representatives of the member states, and the Framework programme requires unanimous approval.

Peter Idenburg, the Dutch representative on CREST, said that his committee had suggested that most, if not all, of the money should be concentrated in the thematic programmes on the key actions, and that these should have clearly defined output. Generic technologies and basic research would still be included in these categories, he said.

Rob Wright, British CREST representative, put it more plainly. "Governments will be extremely hard-nosed," he said. "They will not approve money for projects which are not palpably urgent."

But calls for reduced emphasis on non-targeted basic research were heavily criticized by Borgmann. "ESTA has had the feeling that the commission is now more friendly to basic research than it has been in the past", he said. "We would ask it not to deviate too far - even under pressure from its desire to take a longer-term view of research than industry has to."

At the meeting, the commission defended the matrix-style management system that it has proposed for FP5. Although the proposed management structure has come under attack for its apparent complexity, the commission argues that it will increase flexibility. "It is the only system that could work," said Jorma Routti, director general of the resarch directorate. "As form follows function, in the philosophy of Frank Lloyd Wright, so structure will |follow objective in our management." But commission officials were unable to say how the management structure will operate in practice.

Alison Abbott 